\title{
Silva, C. N., Buček, J. (eds.) (2017): Local government and urban governance in Europe (Springer, Cham, 265 o.)
}

\author{
TIMÁR LÉNÁRD ÁDÁM
}

\begin{abstract}
TIMÁR Lénárd Ádám: PhD-hallgató, Pécsi Tudományegyetem, Interdiszciplináris Doktori Iskola; 7624 Pécs, Ifjúság útja 6.; lenardadamtimar@gmail.com; https:// orcid.org/0000-0002-3625-3603
\end{abstract}

Lénárd Ádám TIMÁR: PhD student, Interdisciplinary Doctoral School, University of Pécs; Ifjúság útja 6., H-7624 Pécs, Hungary; lenardadamtimar@gmail.com; https://orcid.org/0000-0002-3625-3603

Az urbanizmus és a modernizáció fontos társadalmi-gazdasági és jogszabályi változásokat indukál a térben, ezért fontos, hogy megfelelő szakirodalom álljon rendelkezésünkre. Ennek kíván eleget tenni a Springer Kiadó a The urban book series elnevezésű sorozatával. A sorozat egyik legutóbbi kötete a Local government and urban governance in Europe.

1844. február 17-én a rendi országgyülésen felszólalt Házmán Ferenc, Buda szabad királyi város követe. A feljegyzések szerint a következőt mondta: „A városok azon szíverek, mellyek a néptest nedvét magokba felvévén, azt tisztultan és éltetőleg ismét visszaárasztják; a városok azon közvetítők, mellyek nem csak a közjólétet hathatósan előmozdítani, hanem egyszersmind a politicai jog nélkül szükölködő osztályokat a kiváltságos rendek előjogaival kibékíteni a leginkább alkalmasak" (Rendi Napló 2009, 110.). Az idézet tükrözi, hogy a városok és a kisebb helyi közösségek - legalábbis Európában - régóta részei a politikai közbeszédnek. Bár a legutóbbi nemzetközi folyamatok miatt (például a 2008-as gazdasági válság) megerősödtek az erős nemzetállamot követelők, az urbanizmus kérdése továbbra is napirenden maradt. Míg Magyarországon a regionalizmust a centralizáció, addig világszinten a „városok reneszánsza” váltotta fel. A gazdasági válság és más társadalmi-gazdasági folyamatok miatt azonban az utóbbi időben egyre nagyobb szerepet tölt be a városoknak és környezetüknek, illetve a metropoliszoknak egymással való kapcsolata az uniós tervekben és jövőképekben. A változás váratlanul és felkészületlenül érte néhány ország tudósait is (Pálné Kovács 2008).

A Carlos Nuñes Silva és Ján Buček által szerkesztett kötet az európai városfejlődés három jelentős hatására koncentrál, amelyek az elmúlt 60 évet három részre osztják: 1. a demokratikus átmenetek az 1970-es évektől a korai 1990-es

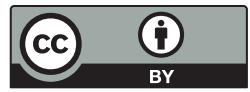


évekig; 2. a 2008-as pénzügyi és gazdasági válság; 3. az Európai Unió várospolitikája. Az első rész négy fejezete az európai helyi önkormányzatok fejlődését és újításait mutatja be. A második rész öt tanulmánya az Európai Unió várospolitikáival és kezdeményezéseivel, az utolsó rész két tanulmánya pedig a helyi önkormányzatok döntési mechanizmusaiban való civil részvétellel foglalkozik.

Utóbbi a legérdekesebb tudományos szempontból, mert gyakorlati és elméleti oldalról is sok kérdést vet fel. Különösen az kötötte le a kutatók figyelmét, hogy hol lehet meghúzni a városi kormányzatok (government) és a városi kormányzás (governance) közötti határt. Előbbihez hagyományosan az adózást, a tervezést és bizonyos társadalmi csoportokról való gondoskodást lehet sorolni (a különféle városkormányzatok szinte automatikusan foglalkoznak ezekkel). Ezzel szemben európai értelemben a kormányzás alatt azt értjük, amikor egy területre nem terjed ki a kormányzat hatásköre, és azt az ott lakóknak maguknak, a civil szektornak kell megszerveznie. Megfigyelhetö, hogy a 2008-as gazdasági válság után sok városban a feladatok egy részét átvette az állam. Történelmi szempontból a városkormányzatok megszervezése az állam intézményesüléséhez kötődik, amely több problémára akart választ adni. Ilyenek például az illegális tevékenységek elszaporodása, a slumosodás, a népesség elköltözése, a járványos betegségek, illetve a szegényebb rétegek szomszédságának elutasítása (Borraz, Le Galès 2017). A kötet bevezető részében a szerkesztők is az urbanisztikai tudományok fontosságát mutatják be.

Az első tanulmányt Carlos Nuñes Silva írta a portugáliai helyi önkormányzatok változásairól. A Salazar-rendszer és az 1974-ben létrehozott II. Köztársaság hatása mindmáig érzékelhető a portugál közigazgatáson. A Salazar-rendszer szubnacionális szintjeinek önállóságát az állam letörte, működésüket erősen kontrollálta (speciális volt a gyarmatok helyzete). Ez a helyzet változott meg a demokratikus alkotmány 1976-os elfogadásával, mely az autonóm önkormányzatok intézményét újra létrehozta. Portugália ettől kezdve unitárius és decentralizált állam lett. Különleges szerepet töltenek be az Azori-szigetek és Madeira, melyek nagyobb önállóságot kaptak a központtól. 1991-ben a nagyobb városi területeken és a szigeteken új közigazgatási modellt vezettek be. A városokban olyan új intézményeket hoztak létre, melyek az urbanizált környékre kiterjedő fennhatósággal és önállósággal rendelkeztek. 2003-ban Lisszabon és Porto esetében ezt váltották fel a nagyvárosi térségek (área metropolitana) koncepciójával, melyet 2013-ban megváltoztattak. A szerző úgy véli, hogy az Európai Unió által (a regionális politikai támogatások előzetes feltételrendszeréről szóló megállapodásban is) szorgalmazott regionalizmus Portugáliában nem az önkormányzatiság kiterjesztésével fog megvalósulni, hanem a települések egymás közötti együttműködéseinek kibővítésével.

Ján Buček tanulmánya az 1990-2015 közötti időszak szlovákiai reformdinamikáit tekintette át. A tanulmány a közigazgatást hagyományos, állami és össztársadalmi nézőpontból vizsgálja, vagyis feltételezi, hogy a reformok célja a társadalmi fejlődés. Az ezzel kapcsolatos szemléletbeli eltérések és az elért 
eredmények megítélése állandó viták tárgya, Szlovákiában is. A tanulmány bemutatja, hogy a háttérben a reformokat milyen erők, csoportok és ideológiák mozgatták (pártpolitikai elképzelések stb.). A szerző azt a következtetést vonta le, hogy a reformok sikerességét több tényező együttese befolyásolta.

Fábián Adrián a magyarországi helyi önkormányzatok 2008-as gazdasági válság utáni helyzetét elemezte, így munkája az előző tanulmányt egészíti ki. A települési önkormányzatok pénzügyi helyzete már korábban is problémás volt, mert nagyban függött a külső forrásoktól. A válság csak ezeket a negatív folyamatokat erősítette meg. A támogatásoktól való függés 1990-től folyamatos emelkedést mutatott, így a hagyományos módon nem lehetett megoldani a felmerült problémákat (Bordás 2017). A szerző következtése, hogy az igazi helyi autonómia a megfelelő szabályozáson múlik, amely biztosítja a közfeladatok ellátását.

A könyv utolsó előtti tanulmányában Lilita Seimuskane, Inga Vilka és Edgar Bregis statisztikai felmérés alapján vizsgálták Litvániában, hogy milyen összefüggésben van a választási részvételi hajlandóság a társadalmi és gazdasági helyzettel. A kutatás tárgyát a 2014-es európai parlamenti és a 2013-as helyi önkormányzati választás képezte. A tanulmány megemlíti, hogy a társadalmi helyzet és a szavazásokon való részvétel vizsgálata az 1940-es, 1950-es években kezdődött el, de Litvániában csak az utóbbi időben került előtérbe. A közvélemény-kutatásokra alapozva a szerzők abból indultak ki, hogy a részvételi hajlandóság a helyi választásokon valószínűleg nagyobb lesz. A vizsgálatokból azt a következtetést vonták le, hogy a gazdasági helyzetnél az egyén végzettsége nagyobb szerepet játszott, a helyi és az európai parlamenti választás esetében is. Utóbbinál a családi helyzet és a lakóhely játszott még fontos szerepet. A részvételi hajlandóságot a helyi önkormányzatok egyedi jellemzői nem befolyásolták.

Werner Fleschberger azt a kérdést járta körül, hogy a jól informált polgárok milyen hatással vannak a helyi önkormányzatok döntéseire. A tanulmány elméleti része a tájékozatlan szavazónak nevezett jelenséget járja körül. Amellett érvel, hogy a közvetlen demokrácia által nyújtott lehetőségek segítenek az önkormányzatok tájékoztatásában, elősegítve a hatékony döntést. A helyi önkormányzatoknak ehhez standardokat kell alkotnia, amelyek alatt a szerző nemcsak a jogszabályokat érti, hanem annak a hallgatólagos meghatározását, hogy a döntésekben kik, melyik szakaszban és milyen formában vehetnek részt. Ad hoc, ügyről ügyre változó forma esetében a döntések nem lesznek hatékonyak és sok esetben az átláthatóság is sérül. A tanulmány második része három példán keresztül mutatja be, hogy a standardok hiánya egy urbánus térség esetén milyen nem várt konfliktusokhoz vezet. A példákból is látszik, hogy az egyes települések egymástól eltérő méretűek, más gazdasági helyzet jellemzi őket és mások a történelmi-politikai tapasztalataik. A választók tájékoztatása azonban minden esetben erősen átpolitizált, ami kihívásként jelentkezik.

A könyvben részletes lábjegyzetek és szakirodalmi apparátus segíti az egyes témák iránt érdeklődőket. A kötet bemutatja az európai kutatók eredményeit a hazai tudományos közélet számára; segítheti a modern, európai városok megér- 
tését a döntéshozók és a tervezők számára. A városok reneszánszára és az uniós politika átalakulására sok állam nem készült fel. Például Budapest és az agglomeráció között hiányzik az intézményesített együttműködés (Tosics 2008), de a modern, jól informált polgárok bevonása a döntések előkészítésébe segíthet elkerülni Bécs hibáját is, amely nem alkotta meg az ehhez szükséges standardokat.

\section{Irodalom}

Bordás P. (2017): Önkormányzati adósságkezelés és költségvetési gazdálkodás. In: Horváth M. T., Bartha I., Varga J. (szerk.): Honnan hová? A közpénzek védelméról. Debreceni Egyetem, Debrecen, 137-154.

Borraz, O., Le Galès, P. (2017): Urban governance of Europe: The government of what? Metropoles, 7., $1-14$.

Pálné Kovács I. (2008): Az új várospolitika kormányzási filozófiája. Tér és Társadalom, 1., 45-57. http://doi.org/c2bn

Rendi Napló (2009): 1844. évi CVI. ülés, február 17. In: Czoch G.: A városok szíverek. Tanulmányok Kassáról és a reformkori városokról. Kalligram, Budapest

Tosics I. (2008): Nagyvárosi kormányzás. Tér és Társadalom, 1., 3-25. http://doi.org/c4d7 